\title{
Experimental study of bolted connections using light gauge channel sections and packing plates at the joints
}

\author{
Ravindra B. Kulkarni • Vishal M. Vaghe
}

Received: 19 September 2012/ Accepted: 9 July 2014/Published online: 20 September 2014

(c) The Author(s) 2014. This article is published with open access at Springerlink.com

\begin{abstract}
Cold-formed structural members are being used more widely in routine structural design as the world steel industry moves from the production of hot-rolled section and plate to coil and strip, often with galvanized and/or painted coatings. Steel in this form is more easily delivered from the steel mill to the manufacturing plant where it is usually cold-rolled into open and closed section members. In the present experimental study, the use of packing plate at the joints in cold-formed channel sections may increase the load carrying capacity and also reduce the buckling of unconnected cold form channel steel plate at joints. The present study focuses on examining the experimental investigation to use mild steel as a packing plate with coldformed channel sections by bolted connection at the joints and the connection subjected to axial tension. Series of tests are carried out with increase in the thickness of packing plate and results are observed and analyzed. Total Twelve experimental tests have been carried out on coldformed channel tension members fastened with single as well as three numbers of bolts at the connection and from the observations the strength of the joint is increased by increasing the various thicknesses of packing plates and also the buckling of unconnected leg of channel specimen is reduced. It is analyzed by plotting the entire load versus elongation path, so that the behavior of the connection is examined.
\end{abstract}

\footnotetext{
R. B. Kulkarni ( $\square)$

Department of Civil Engineering, Gogte Institute of Technology, Belgaum, India

e-mail: kulkarnirbk@rediffmail.com

V. M. Vaghe

Department of Civil Engineering, Tatyasaheb Kore Institute of Engineering and Technology, Warananagar, India
}

Keywords Light gauge steel section · Bolted connection · Mild steel plates · Tension member - Strain/elongation . Failure pattern $\cdot$ Ultimate strength

\section{Introduction}

The use of cold-formed steel (CFS) members in building construction began in the 1850s in both the United States and Great Britain. In the 1920s and 1930s, acceptance of CFS as a construction material was still limited because there was no adequate design standard and limited information on material use in building codes. One of the first documented uses of CFS as a building material is the Virginia Baptist Hospital (Chen 2010), constructed around 1925 in Lynchburg, Virginia. The walls were load bearing masonry, but the floor system was framed with double back-to-back CFS lipped channels. According to Chuck Greene, P.E of Nolen Frisa Associates (Zhao et al. 2005), the joists were adequate to carry the initial loads and spans, based on current analysis techniques. Greece engineered a recent renovation to the structure and said that for the most part, the joists are still performing well. A site observation during this renovation confirmed that "these joists from the 'roaring twenties' are still supporting loads, over 80 years later!" In the 1940s, Lustron Homes built and sold almost 2,500 steel-framed homes, with the framing, finishes, cabinets and furniture made from CFS.

Cold-formed steel is the common term for products made by rolling or pressing thin gauges of sheet steel into goods. CFS goods are created by the working of sheet steel using stamping, rolling, or presses to deform the sheet into a usable product. The use of CFS construction materials has become more and more popular since its initial introduction of codified standards in 1946. In the construction 
industry, both structural and non-structural elements are created from thin gauges of sheet steel. The material thicknesses for such thin-walled steel members usually range from $0.0147 \mathrm{in}$. $(0.373 \mathrm{~mm})$ to about $1 / 4 \mathrm{in}$. $(6.35 \mathrm{~mm})$. Steel plates and bars as thick as $1 \mathrm{in}$. $(25.4 \mathrm{~mm})$ can also be cold-formed successfully into structural shapes. These building materials encompass columns, beams, joists, studs, floor decking, built-up sections and other components. The manufacturing of CFS products occurs at room temperature using rolling or pressing. The strength of elements used for design is usually governed by buckling (Chen 2010).

Over the past two decades, cold-formed steel has seen increased usage as the structural frame for residential and multistory commercial buildings due to inherent features that overcome the downsides of conventional products. Their strength, light weight, versatility, non-combustibility, and ease of production have encouraged architects, engineers, and contractors to use cold-formed steel products which can improve structural function and building performance, and provide esthetic appeal at lower cost. At the same time, cold-formed steel members have a unique structural stability issues primarily due to the large width to thickness comparison element ratios, which is not commonly the use with in sections of hot-rolled steel (Ali et al. 2010)

\section{Review of literatures}

Limited researchers investigated the performance of the cold-formed Steel connections. Munse and Chesson (1963) studied riveted and bolted joints and examined factors that reduce net section capacity, conducted numerous experiments on various specimens and connection details. Prior to these studies, tension member capacity was based solely on gross section yielding or net section rupture. Kulak and $\mathrm{Wu}$ (1997) studied shear lag in bolted angle tension members and examined shear lag effects and presented accountings for shear lag in American and Canadian design specifications (which are based on AISC LRFD specifications), conducted a number of tension tests considering only net section rupture. The failure of these specimens was preceded by a necking down of the net area between the leg edge and lead bolt hole. Rupturing of the specimen initiated at the leg edge and propagated through to the bolt hole and then on through the rest of the specimen. Barth et al. (2002) studied behavior of steel tension members subjected to uniaxial loading and performed load tests on three series of short tension member specimens to investigate the influence of varying connection eccentricity and connection length on the load capacity of the members. Pan (2004) studied the prediction of the strength of bolted cold- formed channel sections in tension and investigated the shear lag effect in bolted cold-formed steel tension members. Shear lag effect occurs when some elements of the tension member are not connected. This effect reduces the strength of the member because the stresses distributed over the entire section are not uniform. Pan (2004) 23Prediction of the Strength of Bolted Cold-Formed Channel Sections in Tension. This study is concentrated on the investigation of the shear lag effect on bolted CFS tension members. Channel sections with different dimensions tested using bolted connections were discussed in this study. Bolandim et al. (2013) Bolted Connections in CFS: Reliability Analysis for Rupture in Net Section paper presents 93 unpublished experimental results for rupture in the net section of bolted connections in CFS angles and channels. The article includes a study of the strength reduction coefficient to account for the shear lag effect. Maiola et al. (2002) Structural Behavior of Bolted Connections in CFS Members, Emphasizing the Shear Lag Effect experimental investigation of bolted connections in cold-formed angles (either equal or unequal legs) and channel members (1.55-3.75 mm thickness), and an evaluation of the structural behavior of the connections with identification of the corresponding failure modes, with emphasis on the tensile capacity of angles and channels.

To enhance the practical use of light gauge sections, studies are still required investigating the structural behavior and performance of connections. There are a number of codes of practice on the design of cold-formed steel structures together with complementary design guides and worked examples to assist practicing engineers. This study will base on the requirements of codes IS: 811-1965, ${ }^{1}$ IS: $801-1975,{ }^{2}$ IS: $1079-1973,{ }^{3}$ IS: $1364-1967^{4}$ and IS: 2062-1992 ${ }^{5}$. IS: 801 (Wallace 2002) does not have any Provisions for the design of tension members. Hence, IS: $800-700^{6}$ Code of practice for use of structural steel in general building construction is used for the inclusion of design provisions.

\footnotetext{
${ }^{1}$ IS: $811-1965$ Specification for cold-formed light gauge structural steel sections.

2 IS: 801-1975 Code of practice for use of cold-formed light gauge steel structural members in general building construction (first revision).

${ }^{3}$ IS: 1079-1973 Specification for hot-rolled carbon steel sheet and strip (third revision).

${ }^{4}$ IS: 1364-1967 Precision and semi-precision hexagon bolts, screws, nuts and lock nuts.

5 IS: 2062-1992 Specification for steel for general structural purposes.

${ }^{6}$ IS: $800-700$ Code of practice for use of structural steel in general building construction.
} 


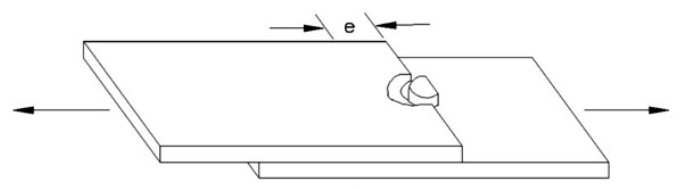

(a)

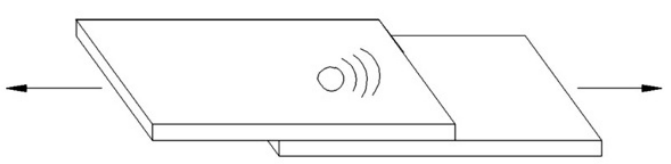

(b)

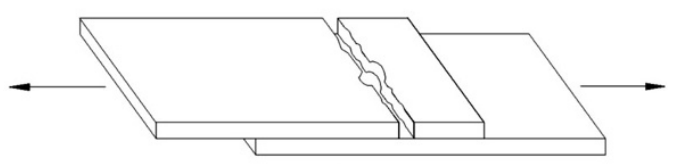

(c)

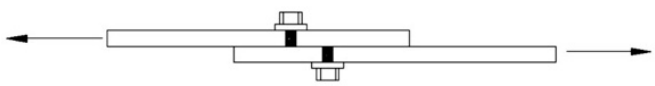

(d)

Fig. 1 Types of failure of bolted connections

\section{Connections}

Connections designed more conservatively than members because they are more complex to analyze, and discrepancy between analysis and design is large. Connections account for more than half the cost of structural steel work. Connection design has influence over member design. Similar to members, connections are also classified as idealized types effected through rivets, bolts or weld. Connections are normally made either by bolting or welding. Bolting is common in field connections, since it is simple and economical to make. Bolting is also regarded as being more appropriate in field connections from considerations of safety.

Types of failure mode in connections (see Fig. 1)

(a) Longitudinal shear failure of sheet (Type I).

(b) Bearing failure of sheet (Type II).

(c) Tearing failure of the sheet (Type III)

(d) Shear failure of bolt (Type IV).

Cover plate bolted connections

The cover plate connection can be a single connection or a part of a more complex connection (Fig. 2). The design approach for gusset plate connections is based on that of IS: 800-2007 (see Footnote 6). A fundamental difference concerns bearing resistances. Partial safety factors to be used in design formulae are bearing: Resistance, governed by yielding, $\gamma_{\mathrm{m} 0} 1.10$ Resistance of member to buckling,
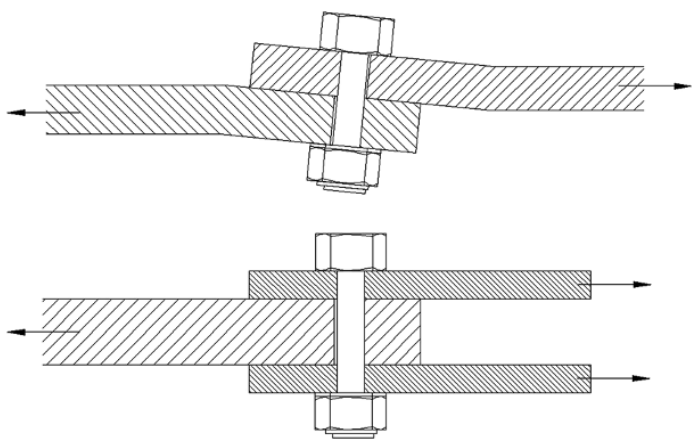

Fig. 2 Connection of basic cover plates with one or two shear planes

$\gamma_{\mathrm{m} 0} 1.10$ Resistance, governed by ultimate stress, $\gamma_{\mathrm{m} 1} 1.25$. The proposed formulae are defined considering various associated failures modes. As the experiment is based on the connection bolts used for connecting, the gusset plate and the specimen are $12 \mathrm{~mm}$ diameter M.4.6 Grade Black Bolts.

\section{Yield strength and Young's modulus of cold form steel plate}

To study the material properties of the sheets used for fabrication of the sections, tension test has been conducted on standard coupons.

The parallel length is kept between " $L_{\mathrm{o}}+b / 2$ and $L_{\mathrm{o}}+2 b "$.

Table 1 shows minimum yield stress of cold form steel plate for the two different thickness and from above results the grade of steel used for the experiment investigation belongs to St. 42 as per IS: 1079-1973 (see Footnote 3) and as per 1996 Edition of the Specification for the Design of CFS Structural Member," and "Specification for the Design of CFS Structural Members,' the type of steel is St. 37 (Germany, Din 17100) or A283C-A (USA, ASTM) for the yield stress $235 \mathrm{~N} / \mathrm{mm}^{2}$.

\section{Packing plate (mild steel) at the connection}

Mildest grade of carbon steel or 'mild steel' is typically carbon steel, with a comparatively mild amount of carbon

Table 1 Yield strength and Young's modulus cold form steel plate

\begin{tabular}{lllll}
\hline $\begin{array}{l}\text { Test } \\
\text { samples } \\
\text { no. }\end{array}$ & $\begin{array}{l}\text { Thickness } \\
\text { of sample } \\
(\mathrm{mm})\end{array}$ & $\begin{array}{l}\text { Yield } \\
\text { stress } \\
\left(\mathrm{N} / \mathrm{mm}^{2}\right)\end{array}$ & $\begin{array}{l}\text { Ultimate } \\
\text { strength } \\
\left(\mathrm{N} / \mathrm{mm}^{2}\right)\end{array}$ & $\begin{array}{l}\text { Young's } \\
\text { modulus } \\
\left(\mathrm{KN} / \mathrm{mm}^{2}\right)\end{array}$ \\
\hline 1 & 1.2 & 231.67 & 358.33 & 191.81 \\
2 & 1.5 & 233.55 & 357.77 & 207.57 \\
\hline
\end{tabular}


(0.16-0.19\%). from the IS: 2062-1992 (see Footnote 5) the grade of the mild steel used for test is E250 (Fe410W) A. The plates were chosen so as to cover or change the failure modes connections. They concern twelve experimental tests with two different thicknesses of specimens. Total nine numbers of mild steel plates are used with different thickness $(2,3,4$, and $5 \mathrm{~mm})$ connected by bolted connection with three numbers of $12 \mathrm{~mm}$ diameter bolts for two sets of two different thickness of specimen. And a single hole with $12 \mathrm{~mm}$ diameter bolt is used to connect the $4 \mathrm{~mm}$ thick
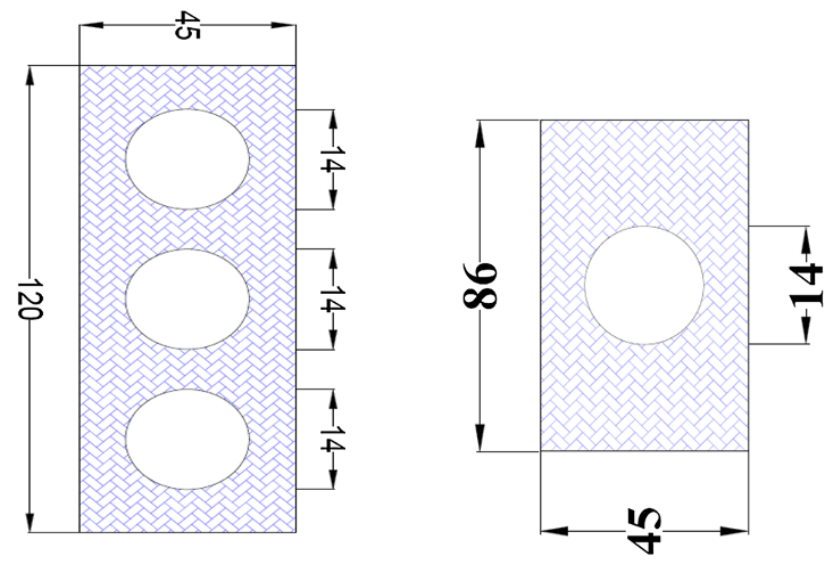

Fig. 3 Cover plate connection with bolt configuration packing plate for $1.5 \mathrm{~mm}$ thick cold form channel specimen. The packing plate with single bolt hole and three bolt hole configurations are shown in Fig. 3 and the c/c bolt hole and edge distance are kept as per IS: 800 (see Footnote 6).

\section{Specimens' geometries}

The experimental testing consists of channel of cold form steel specimens fabricated from rolled steel sheets and the properties of sections were calculated with IS: 811-1965 (see Footnote 1). All specimens are of $500 \mathrm{~mm}$ length and are fastened, with a single row 3 no of $12 \mathrm{~mm}$ diameter Black bolt of M 4.6 black bolt, through their webs at the testing end and 4 no of bolts with a packing plate of $5 \mathrm{~mm}$ thick is attached at the fixed ends IS: 1364-1967 (see Footnote 4). The tests consist of two sets of channel of size $50 \times 40 \mathrm{~mm}$ specimens with 1.2 and $1.5 \mathrm{~mm}$ thickness, with the same connection length for all the samples as shown in Tables 2, 3 and 4, respectively, and the complete connection details of three bolted connection of the specimen shown in Fig. 4. At the connection, packing plates are used of varying thickness. The end distance and number of bolts for each specimen are held constant $2 \mathrm{~d}$ and c/c distance of bolt is kept $3 \mathrm{~d}$ as per IS: 800 (see Footnote 6). Bolts specified are drilled to $14 \mathrm{~mm}$ diameter. In a same way, a single bolt test is done on a $1.5 \mathrm{~mm}$
Table 2 Dimensions for $1.2 \mathrm{~mm}$ thick channel with three bolts connection

All dimensions are in $\mathrm{mm}$

Table 3 Dimensions for $1.5 \mathrm{~mm}$ Thick Channel with 3 Bolts Connection

All dimensions are in $\mathrm{mm}$

\begin{tabular}{lllllll}
\hline $\begin{array}{l}\text { Specimen } \\
\text { size }\end{array}$ & $\begin{array}{l}\text { No. of } \\
\text { bolts }\end{array}$ & $\begin{array}{l}\text { End } \\
\text { distance }\end{array}$ & $\begin{array}{l}\text { Connecting } \\
\text { length }\end{array}$ & $\begin{array}{l}\text { Thickness } \\
\text { of plate }\end{array}$ & $\begin{array}{l}\text { Diameter } \\
\text { of bolt }\end{array}$ & $\begin{array}{l}\text { Diameter } \\
\text { of hole }\end{array}$ \\
\hline $50 \times 40$ & 3 & 24 & 72 & 1.2 & 12 & 14 \\
$50 \times 40$ & 3 & 24 & 72 & 1.2 & 12 & 14 \\
$50 \times 40$ & 3 & 24 & 72 & 1.2 & 12 & 14 \\
$50 \times 40$ & 3 & 24 & 72 & 1.2 & 12 & 14 \\
$50 \times 40$ & 3 & 24 & 72 & 1.2 & 12 & 14 \\
\hline
\end{tabular}

\begin{tabular}{lllllll}
\hline $\begin{array}{l}\text { Specimen } \\
\text { size }\end{array}$ & $\begin{array}{l}\text { No. of } \\
\text { bolts }\end{array}$ & $\begin{array}{l}\text { End } \\
\text { distance }\end{array}$ & $\begin{array}{l}\text { Connecting } \\
\text { length }\end{array}$ & $\begin{array}{l}\text { Thickness of } \\
\text { plate }\end{array}$ & $\begin{array}{l}\text { Diameter of } \\
\text { bolt }\end{array}$ & $\begin{array}{l}\text { Diameter of } \\
\text { hole }\end{array}$ \\
\hline $50 \times 40$ & 3 & 24 & 72 & 1.5 & 12 & 14 \\
$50 \times 40$ & 3 & 24 & 72 & 1.5 & 12 & 14 \\
$50 \times 40$ & 3 & 24 & 72 & 1.5 & 12 & 14 \\
$50 \times 40$ & 3 & 24 & 72 & 1.5 & 12 & 14 \\
$50 \times 40$ & 3 & 24 & 72 & 1.5 & 12 & 14 \\
\hline
\end{tabular}

Table 4 Dimensions for $1.5 \mathrm{~mm}$ thick channel with single bolts connection at the joint

\begin{tabular}{lllllll}
\hline Specimen no. & No. of bolts & End distance & Connecting length & Thickness of plate & Diameter of bolt & Diameter of hole \\
\hline $50 \times 40$ & 3 & 24 & 72 & 1.5 & 12 & 14 \\
$50 \times 40$ & 3 & 24 & 72 & 1.5 & 12 & 14 \\
\hline
\end{tabular}

All dimensions are in $\mathrm{mm}$ 


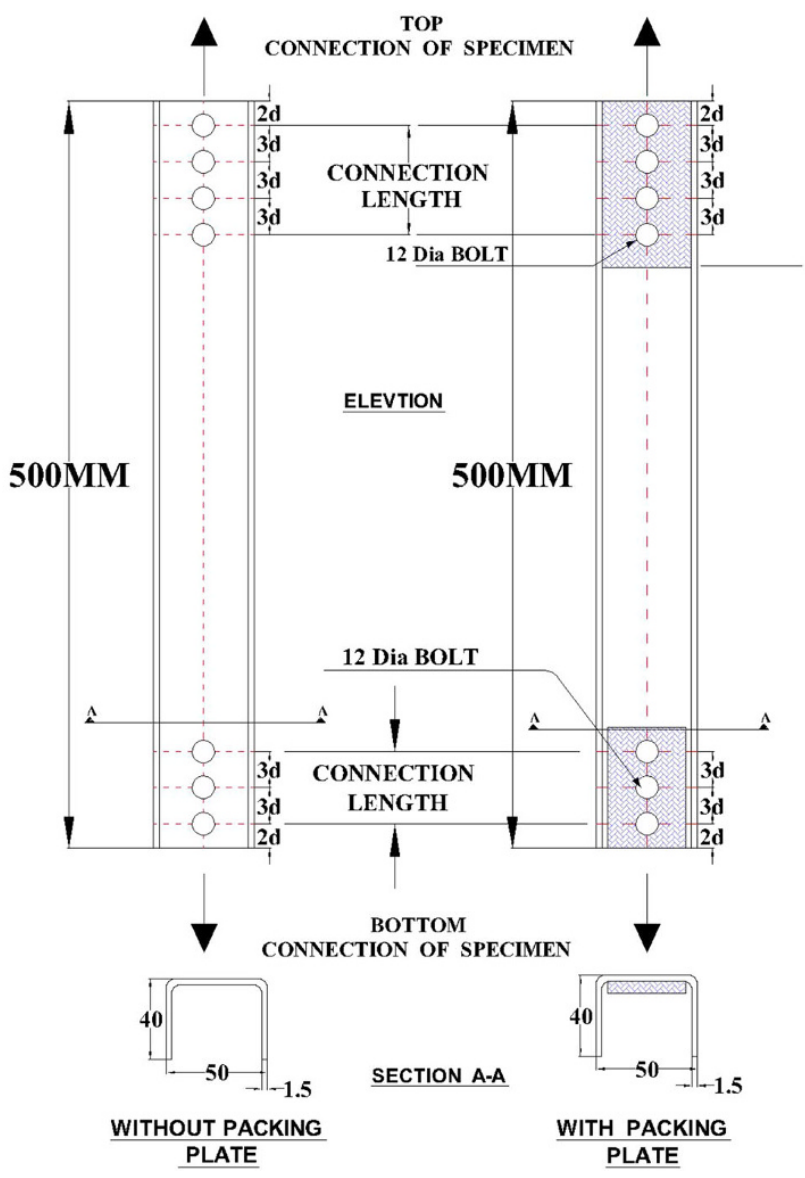

Fig. 4 With three bolted connection at joint

thick channel specimen and the detailed connection of channel is shown in Fig. 5.

\section{Test setup}

Setup of channel section molds, is used to transfer the load from a $1,000 \mathrm{KN}$ universal testing machine (UTM) to a Channel specimen. At the top, a channel sectioned mold is attached to the $10 \mathrm{~mm}$ thick plate with rod and at the bottom a $10 \mathrm{~mm}$ thick plate is attached to the plate attached with rod where failure of section was observed as shown in Fig. 6.

\section{Test descriptions}

The experiments are conducted in three setup of series and are Specimens of Series-A (5 number of $1.2 \mathrm{~mm}$ thick channel specimen with three numbers of bolts at the joint). Specimens of Series-B (five number of $1.5 \mathrm{~mm}$ thick channel specimen with three numbers of bolts at the joint).

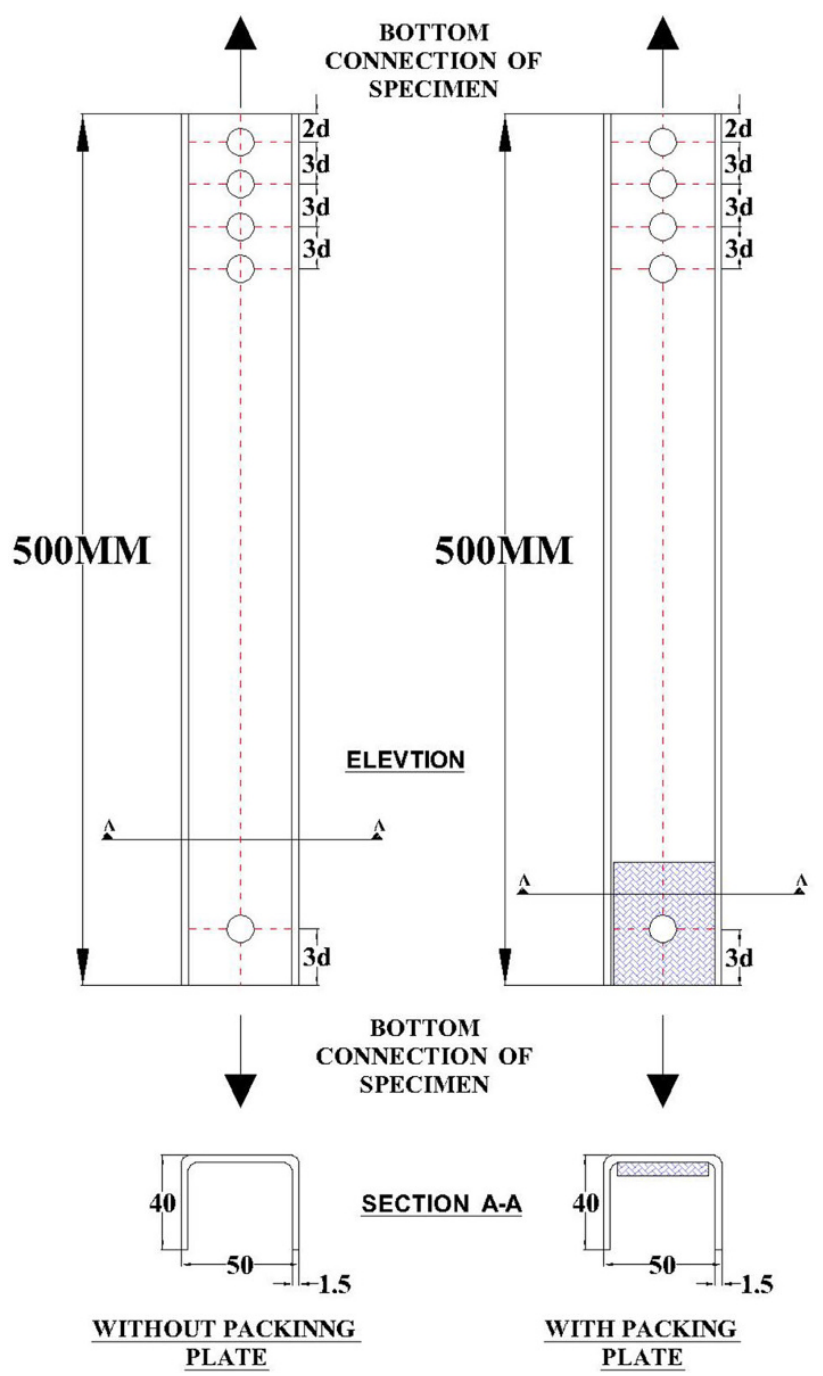

Fig. $51.5 \mathrm{~mm}$ Thick sample with single bolted connection at joint

In both the specimen series A and B, these five specimens having same cross section where first sample is tested without packing plate and remaining samples are tested using packing plate of varying thickness i.e., 2, 3, 4, and $5 \mathrm{~mm}$. Specimens of Series-C (two number of $1.5 \mathrm{~mm}$ thick channel specimen with single bolt at the joint). In this, two specimens are used having the same cross section and the thickness of the packing plate used was $4 \mathrm{~mm}$, where first sample is tested without packing plate. The results will be plotted to load vs. deformation curves for the specimens.

\section{Effects of connection and test parameters}

The photographic view of the test setup is shown in Figs. 7, 8 and 9 . A $1,000 \mathrm{kN}$ capacity universal testing machine is used for applying the tensile load over the specimen. The 
Fig. 6 Moulds for the proper grip used for connecting channel section to UTM for tensile test

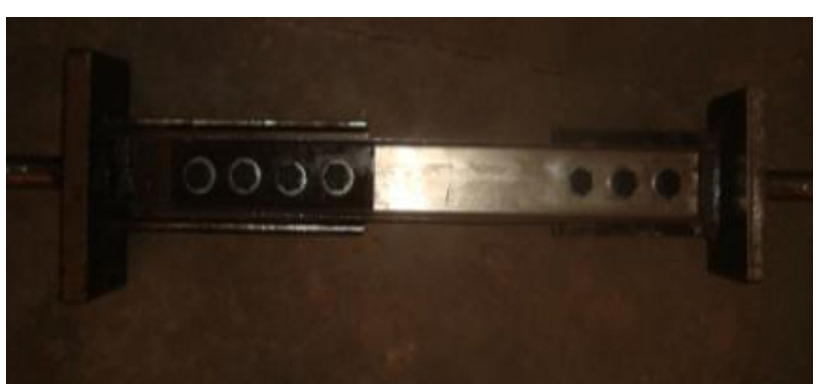

Fig. 7 Setup attached with CFS channel specimen

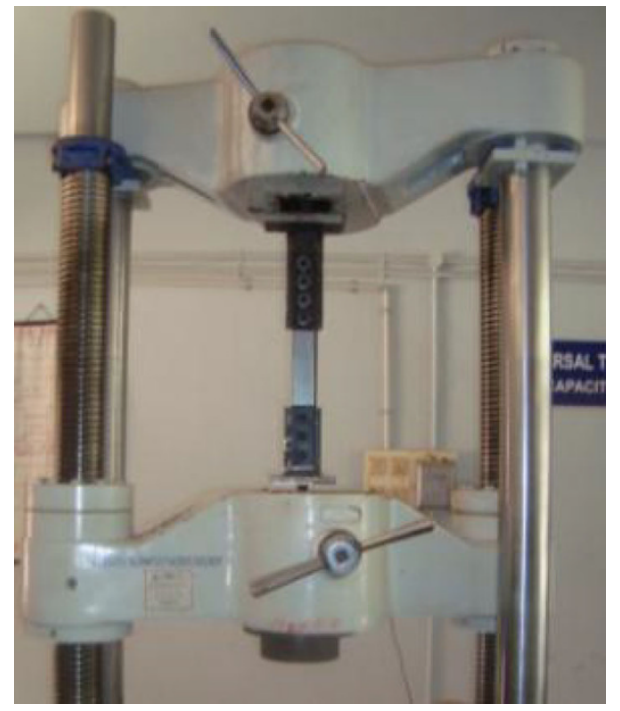

Fig. 8 Testing of channel tension member

load was applied quasi-statically. Readings of load and displacement were taken at regular intervals. The gusset plates are held between the tension grips of the UTM by mold prepared shown in Fig. 6. The channel specimens are connected to the gusset plate with $12 \mathrm{~mm}$ diameter Black bolts of M4.6 Grade IS: 1364 (see Footnote 4). The tensile load is gradually applied through the UTM at a strain rate of $1 \mathrm{~mm}$ per minute in a displacement controlled manner. Besides the strength of the members, the strain distribution at the critical section and the deformations of the specimens are also measured. During the loading process, end fixture and the gusset plates remained straight. As the load increased, the unconnected portion at the two ends of the specimens bent inwards towards the bolt line as shown in the Fig. 10. It is observed that the bending of the unconnected leg is found to be more for the specimen without packing plate i.e., SMPL-A1 SMPL-B1 due to the connection eccentricity, the specimen axis gradually started aligning towards the C.G line during the test. Yielding started first at the critical section around the bolt holes. With further increase in load, the necking initiated near the cross section of the first leading bolt hole. Then, the fracture started at the edges of the bolt hole to channel of connected leg and proceeded towards the unconnected leg Fig. 11. To reduce the bending of unconnected leg and increase the load carrying capacity, packing plates are used. SMPL-A2 and SMPL-B2 is tested using $2 \mathrm{~mm}$ thick packing plate yielding occurred in same way with bending of the packing plate and channel at unconnected shown in Fig. 12, Tables 3 and 4. SMPL-A3, A4, A5, B3, B4, and B5 are tested and it is observed that as the thickness of packing plate increases, the variation in the bending of packing plate as well as specimen is reduced shown in Figs. 3, 13 and 14, and also the load carrying capacity increased; the details are shown in Tables 5 and 6 for the 1.5 and $1.2 \mathrm{~mm}$ thick specimens, respectively. SMPL-CA AND SMPL-CB is tested for single bolt with $4 \mathrm{~mm}$ thick 


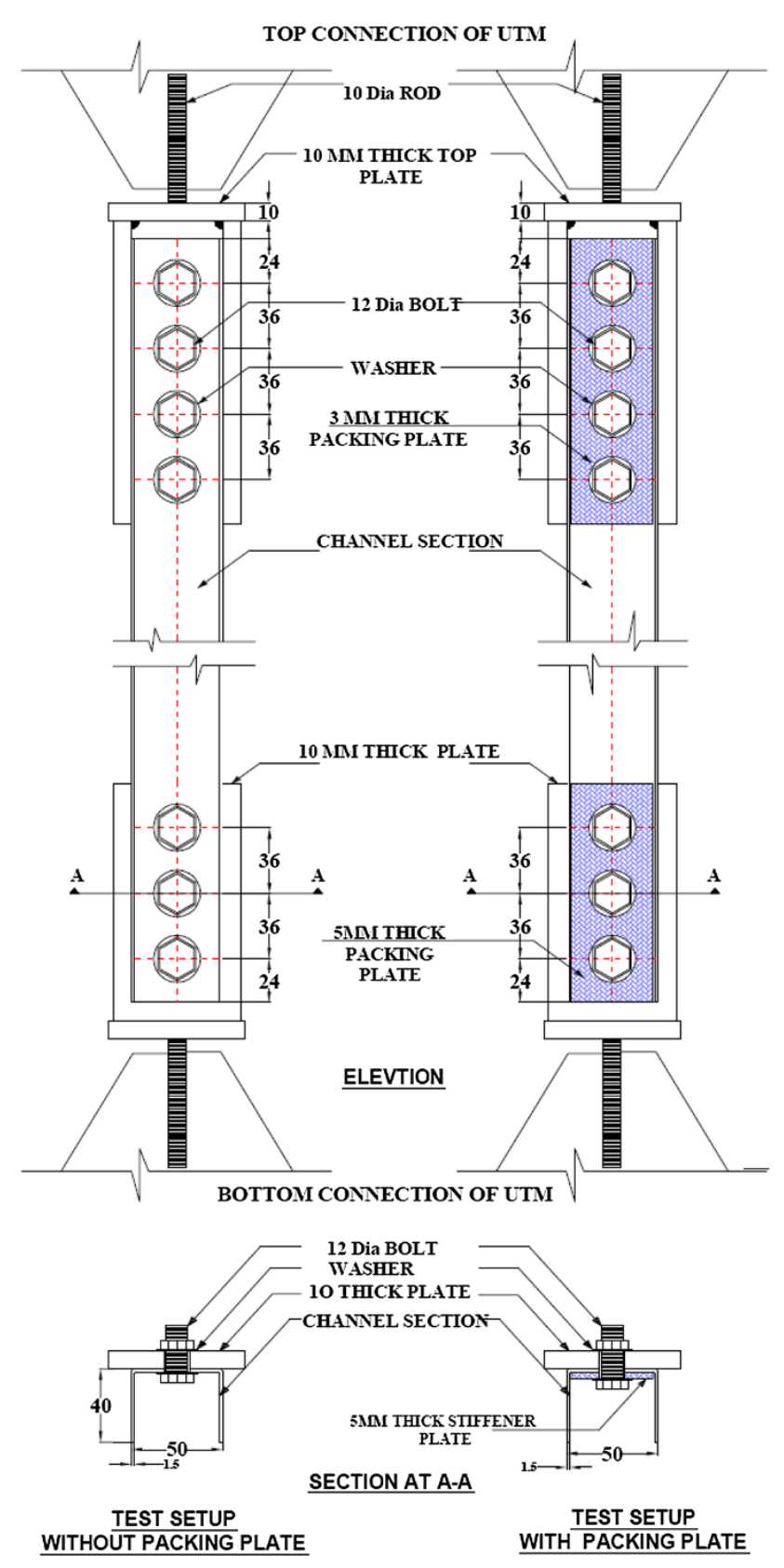

Fig. 9 Detailed arrangement of the test setup for tensile testing in UTM

packing plate at the connection and the details in variation of plate and packing plate and load are shown in Table 7. All the four types of failure are observed in these tests i.e., bearing failure; net section rupture failure, longitudinal shear failures and Block shear failure.

\section{Load-deformation and load-strain response}

Typical load versus elongation curves are plotted for all the specimens and are shown in Figs. 15 and 16. The total elongation of the specimen forms the horizontal axis and

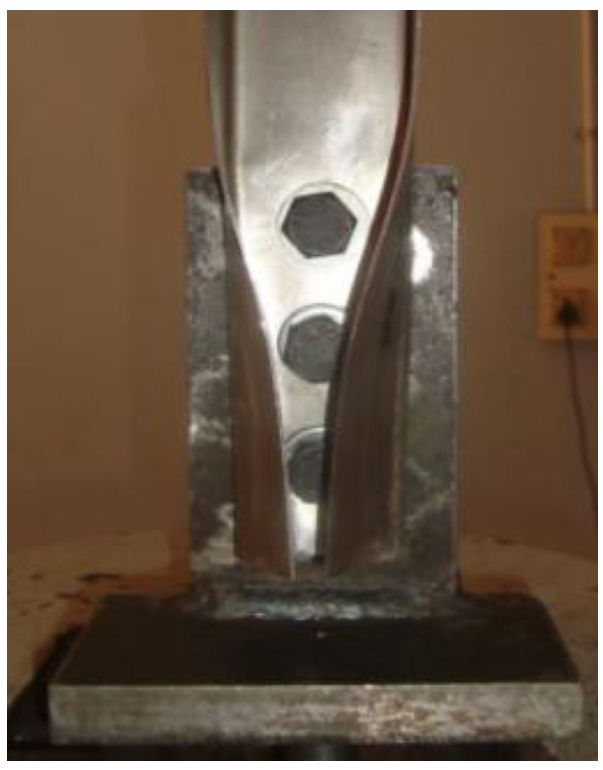

Fig. 10 Bending of unconnected leg of sample

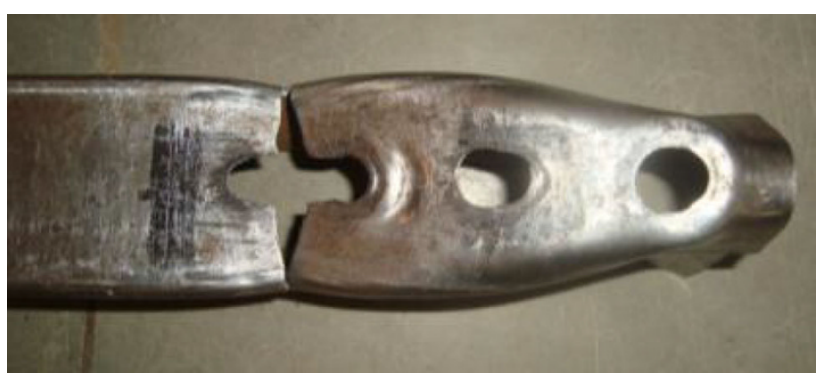

Fig. 11 Fractures started at the edges of the bolt

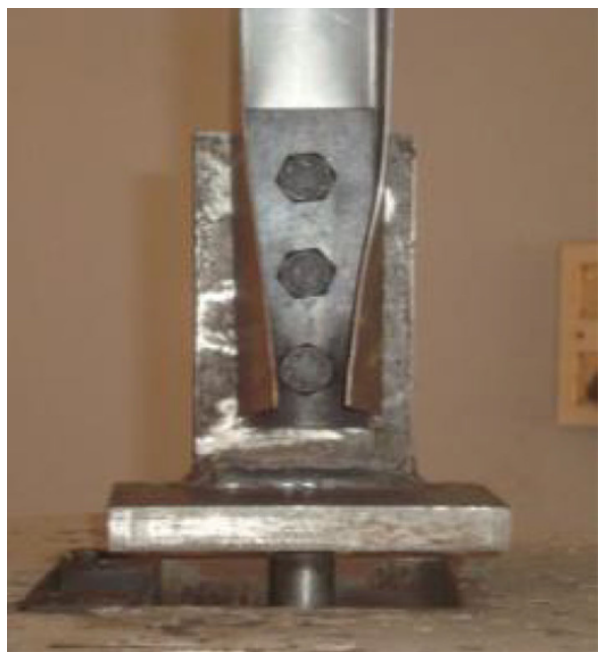

Fig. 12 Bending of the $2 \mathrm{~mm}$ thick packing plate with specimen

the vertical axis gives the corresponding axial load. All the specimens exhibited ductile behavior. Out of 12 specimens, the Channel specimen (SMPL-A5) carried the 


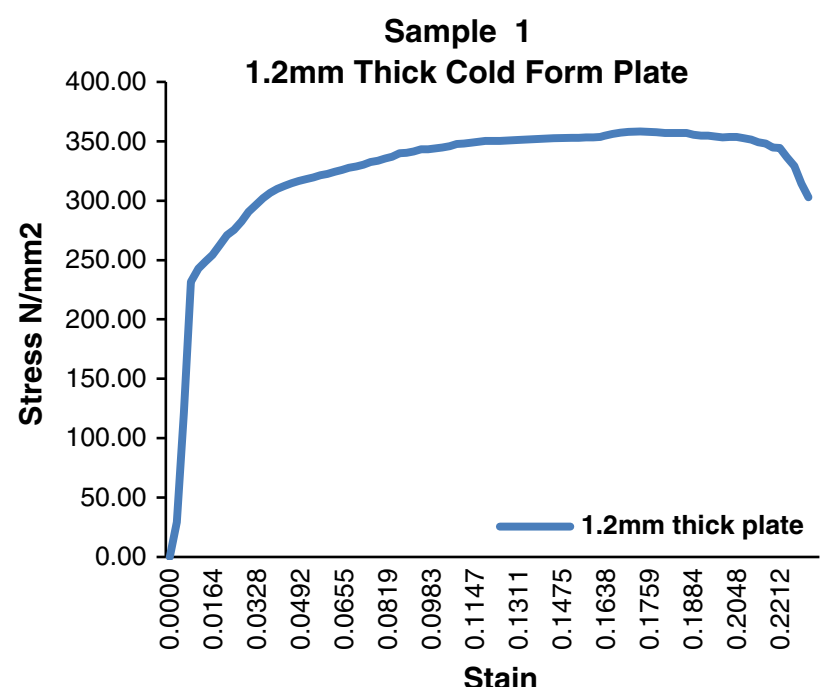

Fig. 13 Variation of stress and strain for $1.2 \mathrm{~mm}$ thick cold form plate

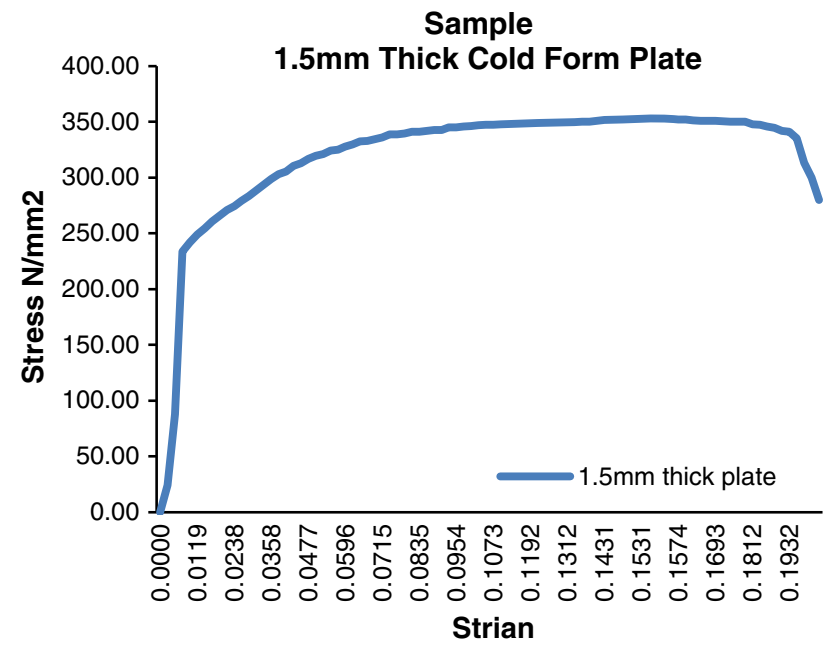

Fig. 14 Variation of stress and strain for $1.5 \mathrm{~mm}$ thick cold form plate

highest ultimate load of $43.5 \mathrm{KN}$ i.e., $26.9 \% 3$ bolt connection and SMPL-CB 17.4 KN i.e., $35.40 \%$ for single bolt connection. The load deformation behavior is linear initially. With the increase in load, yielding started at the vicinity of the lead bolt region and extended towards the unconnected leg causing the non-linear behavior of the material.

Effect of the packing plate at joint

To study the effect of channel of size $(50 \times 40)$ with varying thickness of packing plate were selected. The cold form sections are having thin sections and fails at the bolted connection due to bearing and rupture along with buckling. The introduction of packing plate at bolted connections distributes load over wide area of cold form channel webs and also avoids buckling of web element and hence increases the load carrying capacity of the joint. It is observed that as the packing plate thickness increases, the bending of channel at unconnected leg decreases. With the increase in the thickness of packing plate, a total of $5.8 \%$ average increase in the strength of the each specimen is observed in $1.2 \mathrm{~mm}$ specimen sample. And $5.5 \%$ of average increase in the strength of the each specimen is observed in $1.5 \mathrm{~mm}$ thick specimen. The above results are for the joints of three bolted connections. For single bolt connection, the percentage of increase in the joint is more due to length of outstanding.

\section{Test results with load-deformation and load-strain graphs}

Specimens of Series-A (1.2 mm thick channel specimen with three numbers of bolts at the joint) (See Figs. 15, 17, 18, 19, 20, 21, 22 and Table 5).

Specimens of Series-B (1.5 mm thick channel specimen with three numbers of bolts at the joint) (See Figs. 16, 23, 24, 25, 26, 27, 28 and Table 6).

Specimens of Series-C (1.5 mm thick channel specimen with single bolt at the joint) (See Figs. 29, 30, 31 and Table 7).

\section{Failure patterns}

See Figs. 1, 6, 15, 16, 18, 19, 20, 21, 22, 25, 26, 27, 28, 29, $30,31,32,33,34,35,36,37,38,39,40,41,42$ and 43 .
Table 5 Results of all five $1.2 \mathrm{~mm}$ thick cold form channel specimen

\begin{tabular}{lllllc}
\hline $\begin{array}{l}\text { Specimen } \\
\text { no. }\end{array}$ & $\begin{array}{l}\text { Net section } \\
\text { area }\left(\mathrm{mm}^{2}\right)\end{array}$ & $\begin{array}{l}\text { Ultimate tensile } \\
\text { strength }(\mathrm{kN})\end{array}$ & $\begin{array}{l}\text { Thickness of } \\
\text { packing plate }(\mathrm{mm})\end{array}$ & $\begin{array}{l}\text { Elongation at } \\
\text { peak load }(\mathrm{mm})\end{array}$ & $\begin{array}{l}\text { \% of increase } \\
\text { in strength }\end{array}$ \\
\hline SMPL-A1 & 136.32 & 34.16 & - & 31.00 & 0.00 \\
SMPL-A2 & 136.32 & 35.90 & 2 & 35.40 & 4.60 \\
SMPL-A3 & 136.32 & 37.50 & 3 & 40.80 & 7.15 \\
SMPL-A4 & 136.32 & 40.90 & 4 & 41.20 & 19.60 \\
SMPL-A5 & 136.32 & 43.50 & 5 & 43.80 & 26.90 \\
\hline
\end{tabular}


Table 6 Results of all five $1.5 \mathrm{~mm}$ thick cold form channel specimen

\begin{tabular}{lllllc}
\hline $\begin{array}{l}\text { Specimen } \\
\text { no. }\end{array}$ & $\begin{array}{l}\text { Net section } \\
\text { area }\left(\mathrm{mm}^{2}\right)\end{array}$ & $\begin{array}{l}\text { Ultimate tensile } \\
\text { strength }(\mathrm{kN})\end{array}$ & $\begin{array}{l}\text { Thickness of } \\
\text { packing plate }(\mathrm{mm})\end{array}$ & $\begin{array}{l}\text { Elongation at } \\
\text { peak load }(\mathrm{mm})\end{array}$ & $\begin{array}{l}\text { \% of increase } \\
\text { in strength }\end{array}$ \\
\hline SMPL-B1 & 169.5 & 42.40 & - & 42.80 & 0.00 \\
SMPL-B2 & 169.5 & 44.90 & 2 & 43.20 & 4.90 \\
SMPL-B3 & 169.5 & 46.90 & 3 & 45.40 & 9.50 \\
SMPL-B4 & 169.5 & 48.80 & 4 & 48.80 & 14.00 \\
SMPL-B5 & 169.5 & 50.40 & 5 & 53.60 & 20.00 \\
\hline
\end{tabular}

\begin{tabular}{lllllc}
\hline $\begin{array}{l}\text { Specimen } \\
\text { no. }\end{array}$ & $\begin{array}{l}\text { Net section } \\
\text { area }\left(\mathrm{mm}^{2}\right)\end{array}$ & $\begin{array}{l}\text { Ultimate tensile } \\
\text { strength }(\mathrm{kN})\end{array}$ & $\begin{array}{l}\text { Thickness of } \\
\text { packing plate }(\mathrm{mm})\end{array}$ & $\begin{array}{l}\text { Elongation at } \\
\text { peak load }(\mathrm{mm})\end{array}$ & $\begin{array}{l}\% \text { of increase } \\
\text { in strength }\end{array}$ \\
\hline SMPL-1 & 136.32 & 12.85 & - & 24.00 & 0.00 \\
SMPL-2 & 136.32 & 17.40 & 4 & 28.00 & 35.40 \\
\hline
\end{tabular}

Table 7 Results of $1.5 \mathrm{~mm}$ thick channel section with single bolt at joint

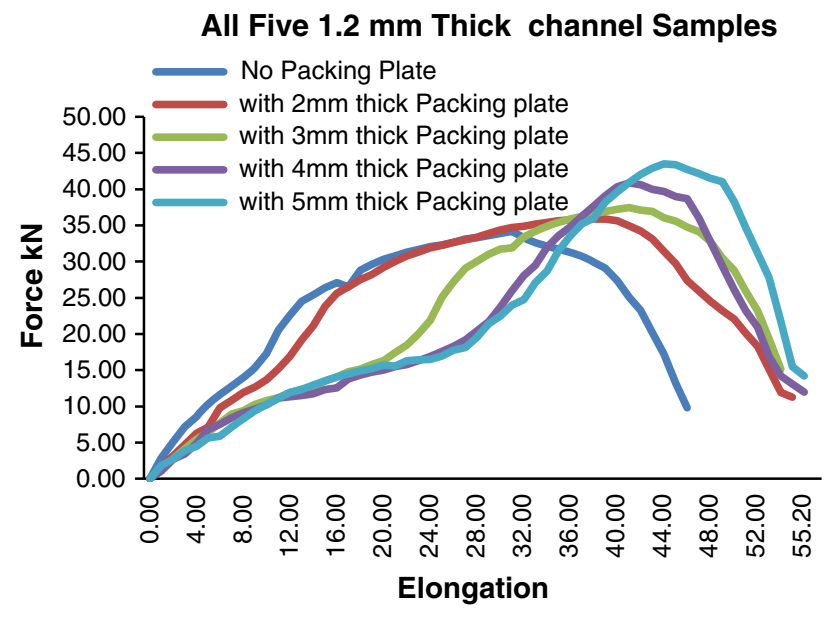

Fig. 15 The graph represents, $1.2 \mathrm{~mm}$ thick all the five samples with different packing plates are compared by combining all the graphs

\section{Discussions and conclusions}

1. It is observed from the above Tables by the use of packing plates that the load carrying capacity of the joint increases. As the thickness of the light gauge section increases, the variation in increase of joint strength reduces for various thicknesses of packing plates.

2. For $1.2 \mathrm{~mm}$ thick channel section, it is observed that all failures are due to rupture with three bolts connection, and also for $1.5 \mathrm{~mm}$ thick channel section up to $3 \mathrm{~mm}$ thick packing plate, the failure

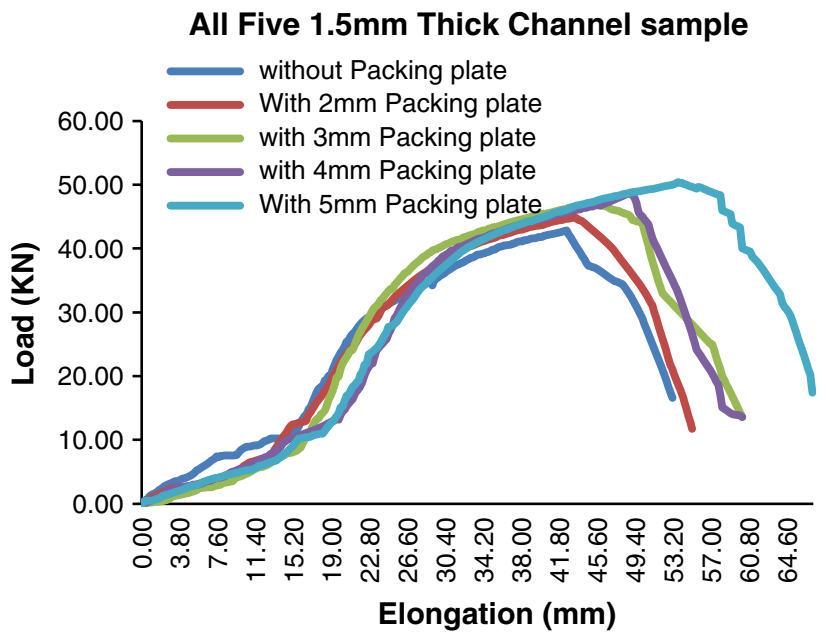

Fig. 16 The graph represents, $1.5 \mathrm{~mm}$ thick all the five samples with different packing plates are compared by combining all the graphs

is due to rupture and for $4 \mathrm{~mm}$ thick packing plate the failure is due to vertical shear failure along the line of vertical connection. With use of $5 \mathrm{~mm}$ thick packing plates, the failure is due to block shear failure.

3. Hence, with the use of thicker plates, bearing failure can be avoided. The increase in the tensile strength for change in each thickness of the packing plate is shown in Tables 8, 9 and 10.

4. By the use of lesser thickness of the Packing plate, it is observed that the plate buckles along with the plate. 


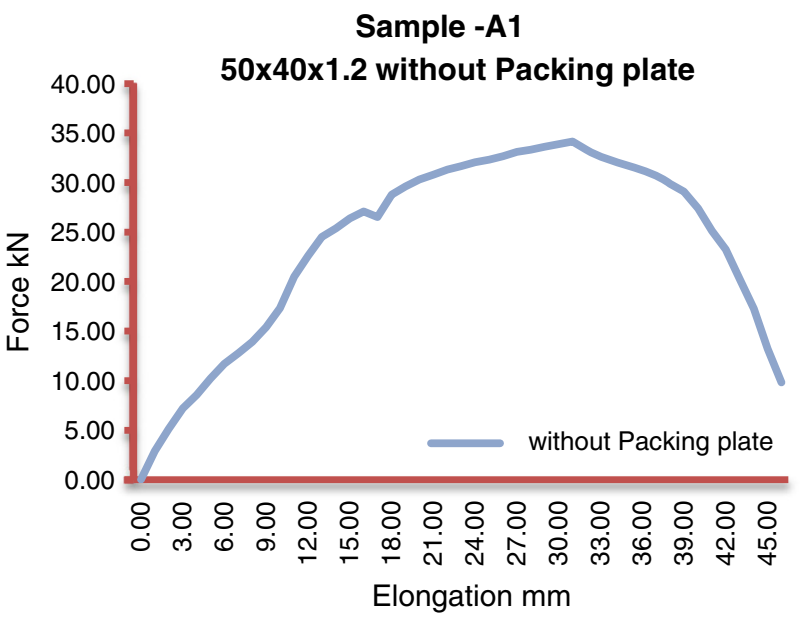

Fig. 17 Graph between force elongation for SMPL-A1 without packing plate

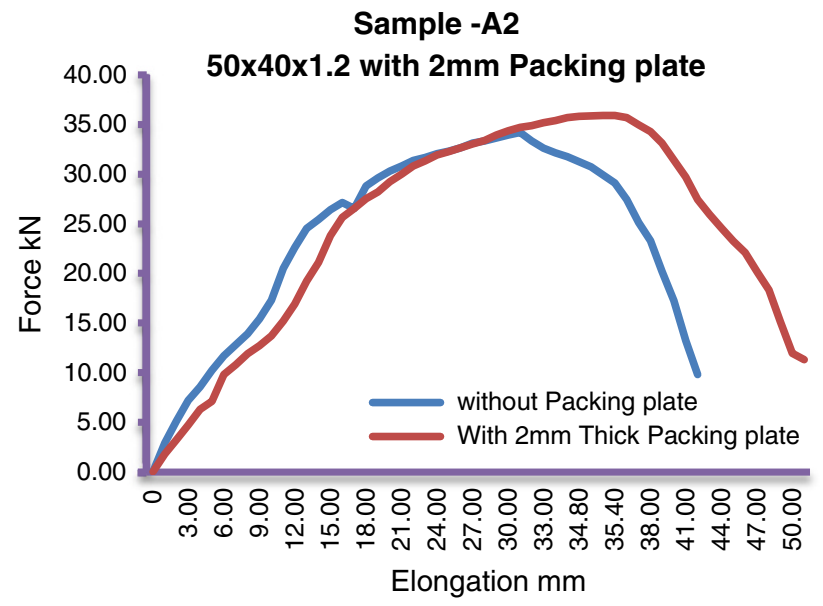

Fig. 18 Comparison graph between force elongation for SMPL-A2 with $2 \mathrm{~mm}$ thick packing plate

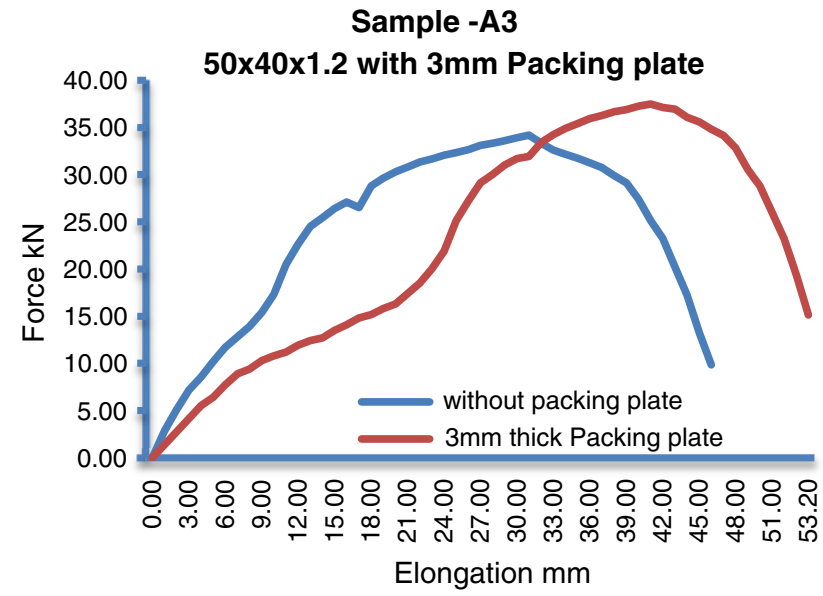

Fig. 19 Comparison graph between force elongation for SMPL-A3 with $3 \mathrm{~mm}$ thick packing plate

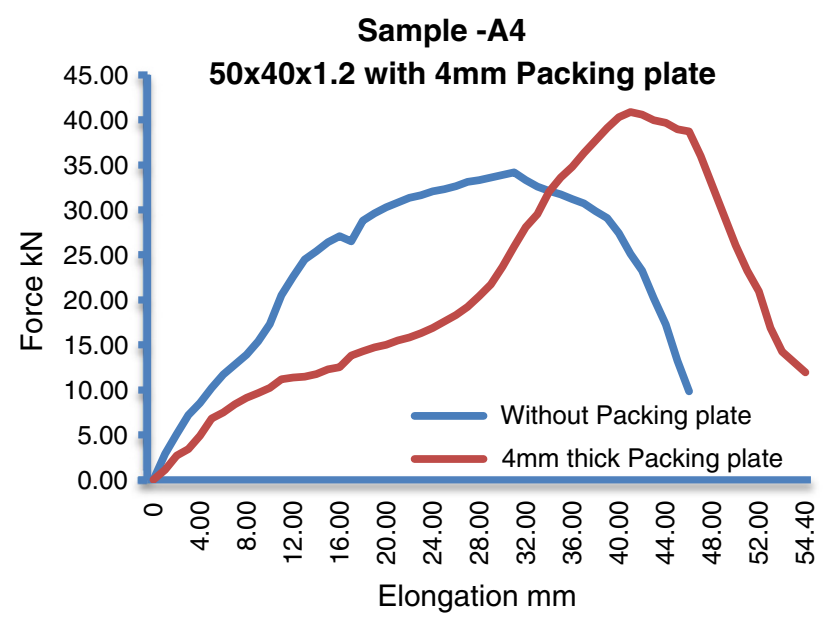

Fig. 20 Comparison graph between force elongation for SMPL-A4 with $4 \mathrm{~mm}$ thick packing plate

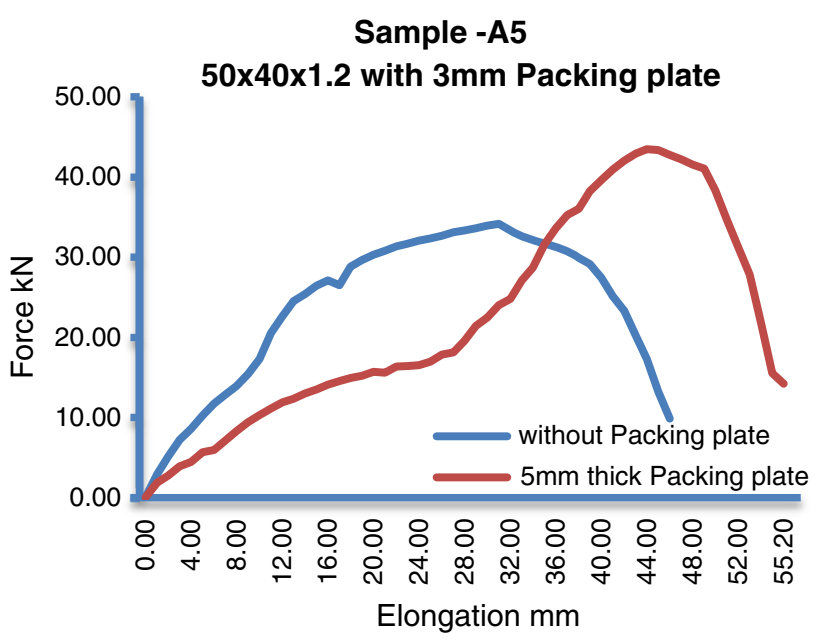

Fig. 21 Comparison graph between force elongation for SMPL-A5 with $5 \mathrm{~mm}$ thick packing plate

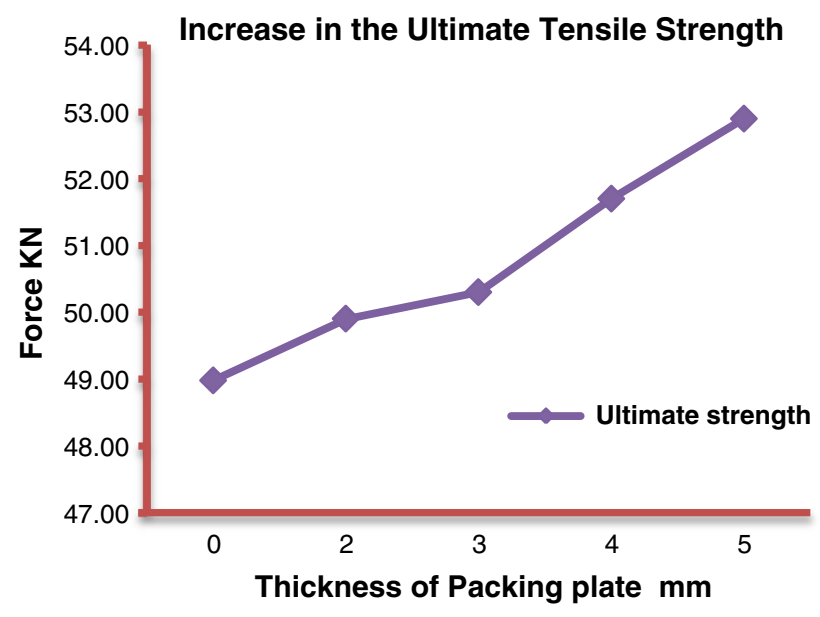

Fig. 22 Graph between thicknesses of the packing plate to ultimate strength 


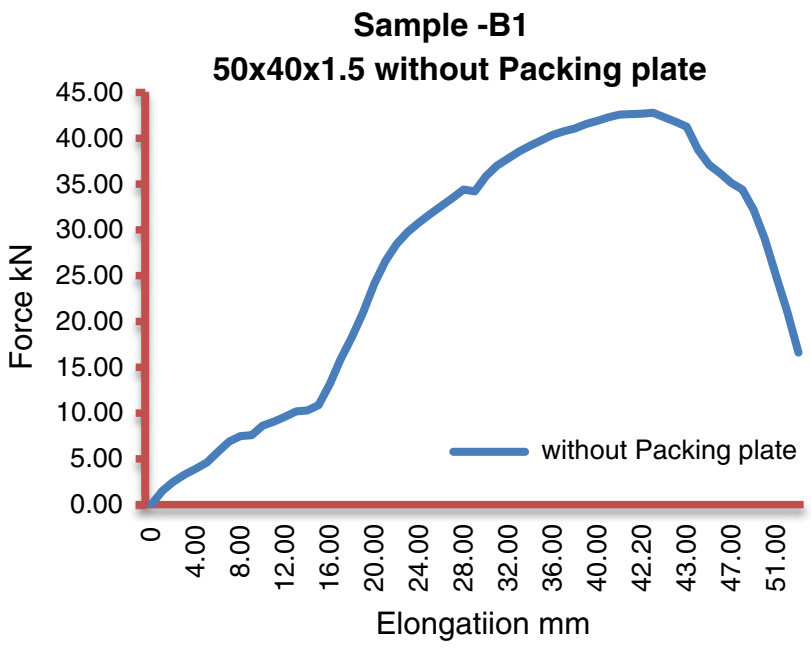

Fig. $231.5 \mathrm{~mm}$ Thick sample with single bolt connection at joint performed test without packing plate

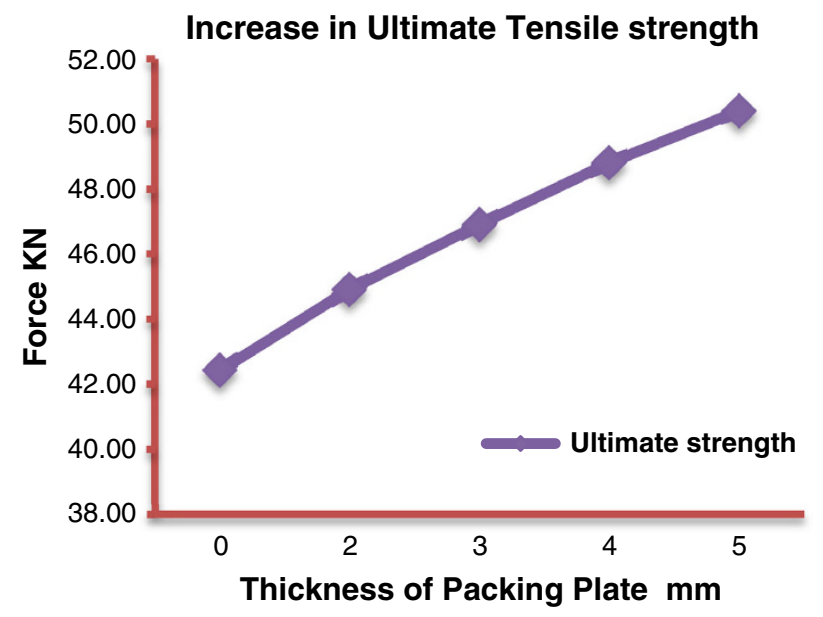

Fig. 24 Graph representing the increase in strength of $1.5 \mathrm{~mm}$ thick packing plate with different thickness

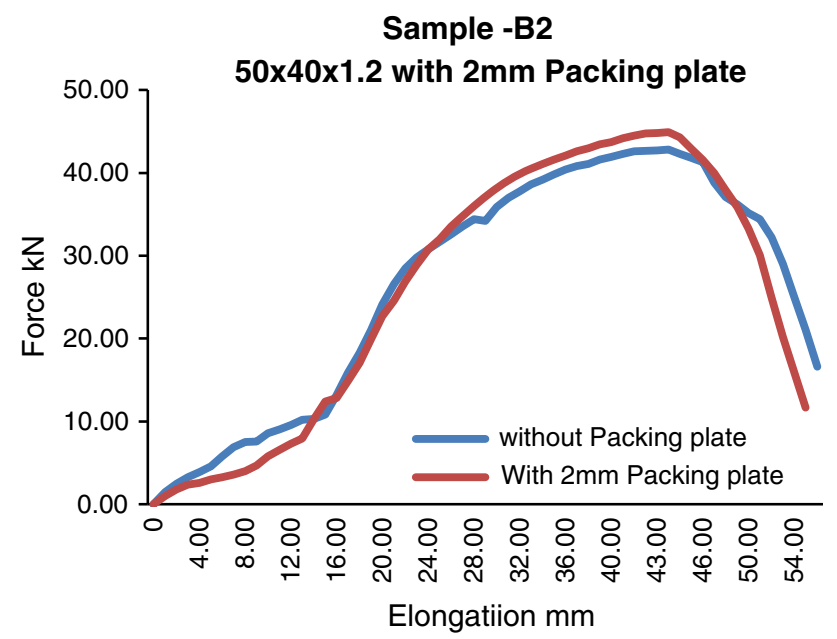

Fig. 25 Comparison graph between force elongation for SMPL-B2 with $2 \mathrm{~mm}$ thick packing plate

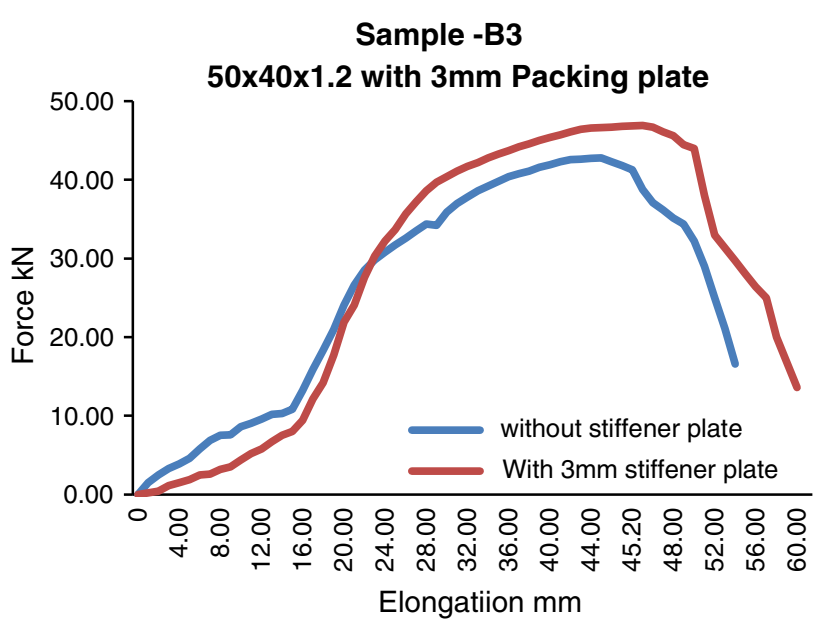

Fig. 26 Comparison graph between force elongation for SMPL-B3 with $3 \mathrm{~mm}$ thick packing plate

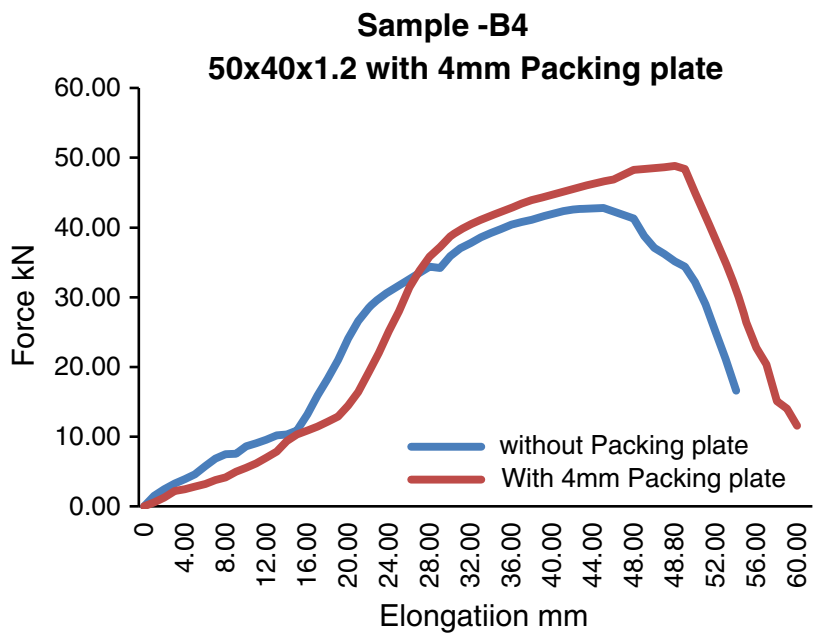

Fig. 27 Comparison graph between force elongation for SMPL-B4 with $4 \mathrm{~mm}$ thick packing plate

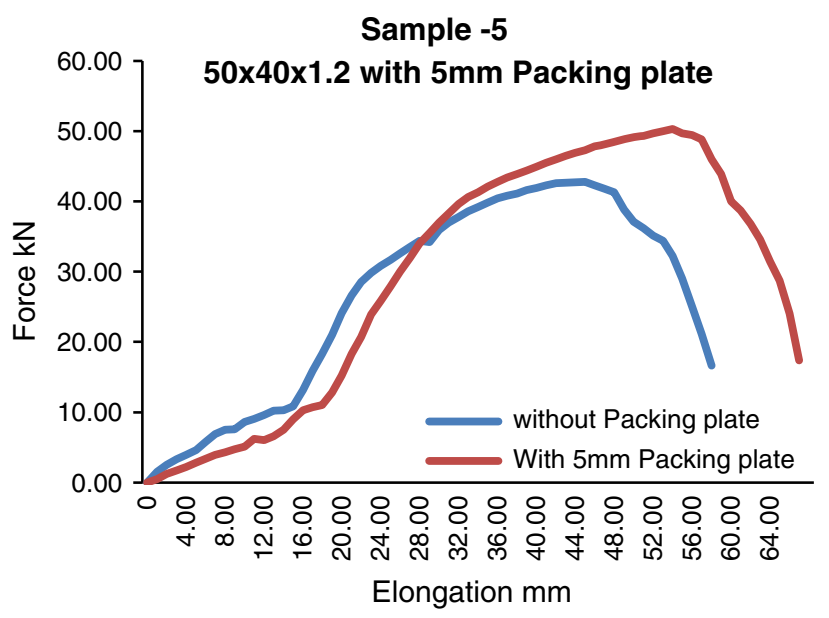

Fig. 28 Comparison graph between force elongation for SMPL-B5 with $5 \mathrm{~mm}$ thick packing plate 


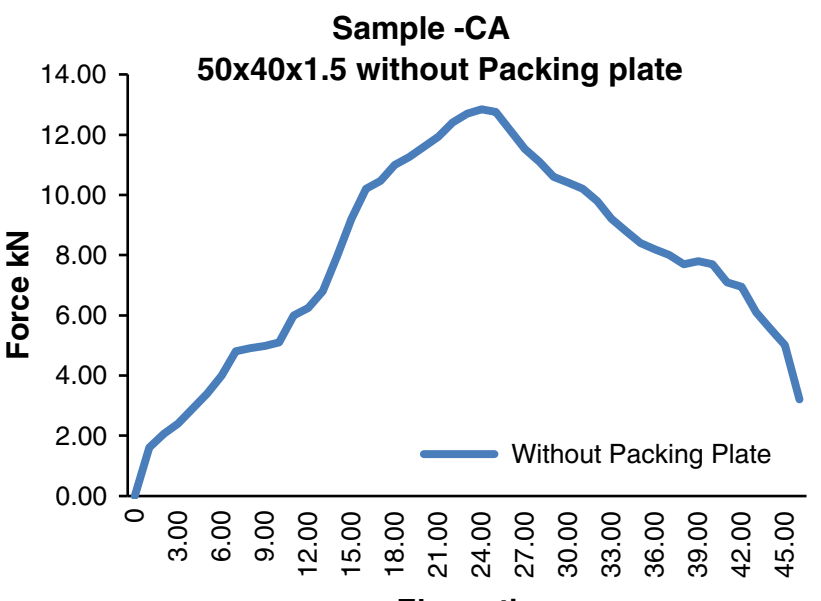

Elongation

Fig. 29 Between force and elongation for specimen SMPL-CA without packing plate

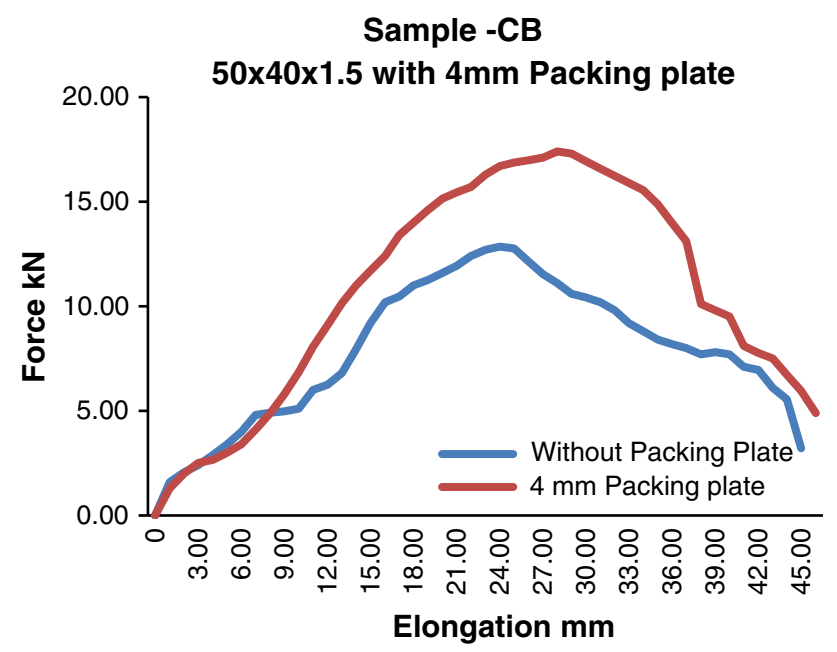

Fig. 30 Graph between force and elongation for specimen SMPL-CB with $4 \mathrm{~mm}$ packing plate

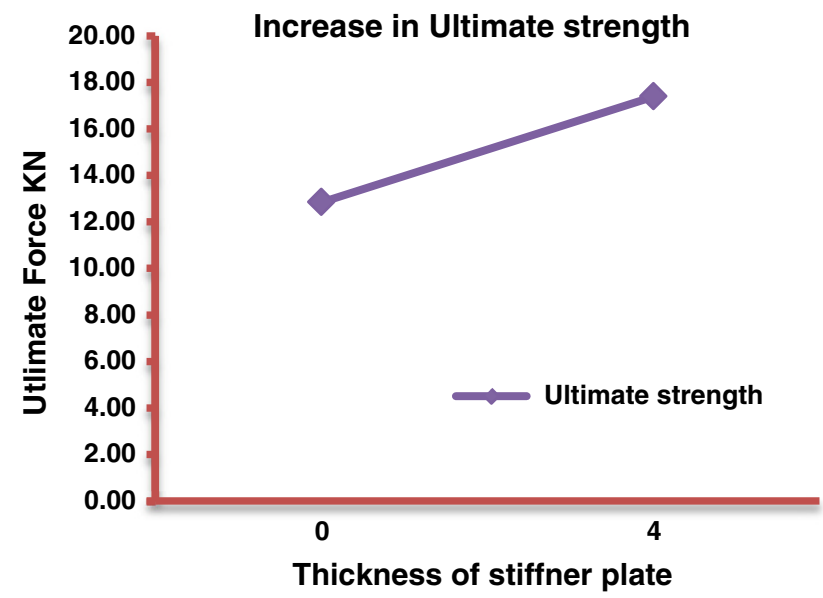

Fig. 31 Graph between thicknesses of the packing plate to ultimate strength

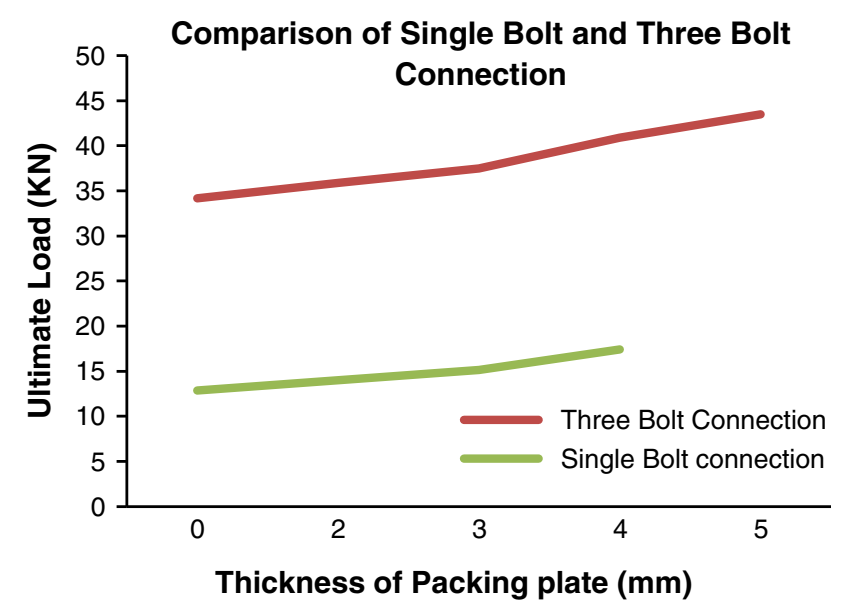

Fig. 32 Graph between thicknesses of the packing plate to ultimate strength for three and single bolted connections

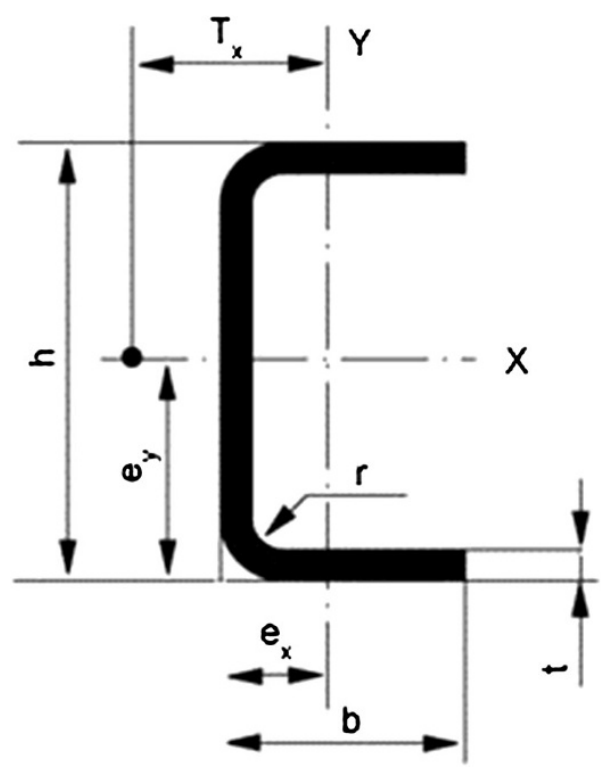

Fig. 33 Cross section details of channel section where, $h$ is the height of the section, $b$ is the width of the section, $t$ is the thickness of the section, $r$ is the radius section $I_{\mathrm{xx}}$ and $I_{\mathrm{yy}}$ is the moment of inertia about $x$ and $y$ axis

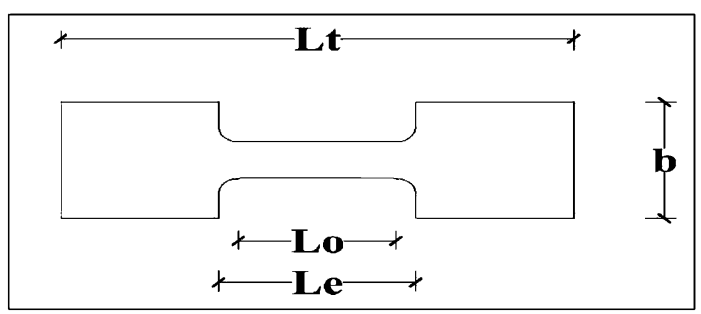

Fig. 34 Tensile test on cold formed steel sheet where, $L_{\mathrm{o}}$ is the original gauge length, $L_{\mathrm{e}}$ is the parallel length, $L_{\mathrm{t}}$ is the total length, $b$ is the width of the test piece 


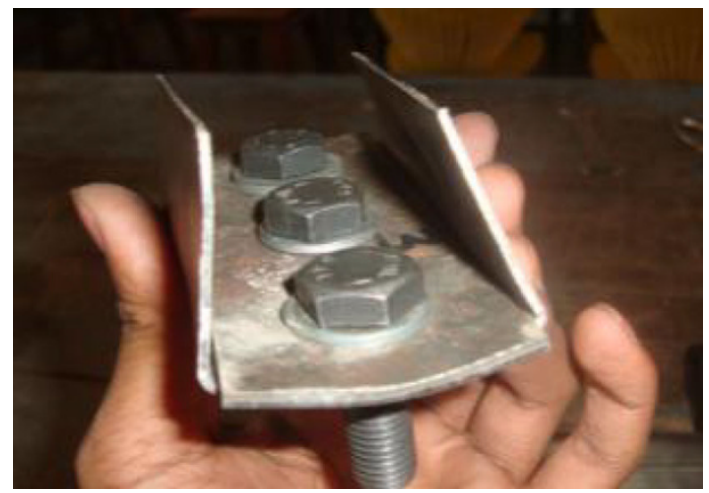

Fig. 35 Reduction bending of the $3 \mathrm{~mm}$ thick packing plate with specimen

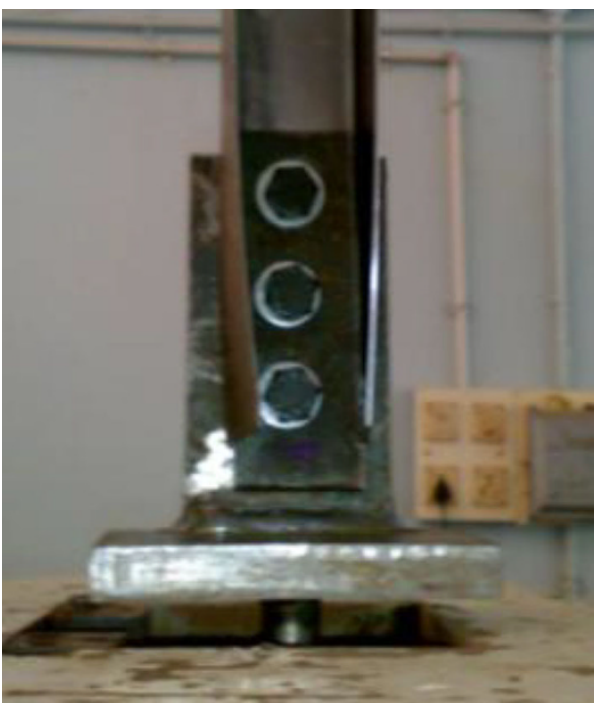

Fig. 36 Reduction bending of the $5 \mathrm{~mm}$ thick packing plate with specimen

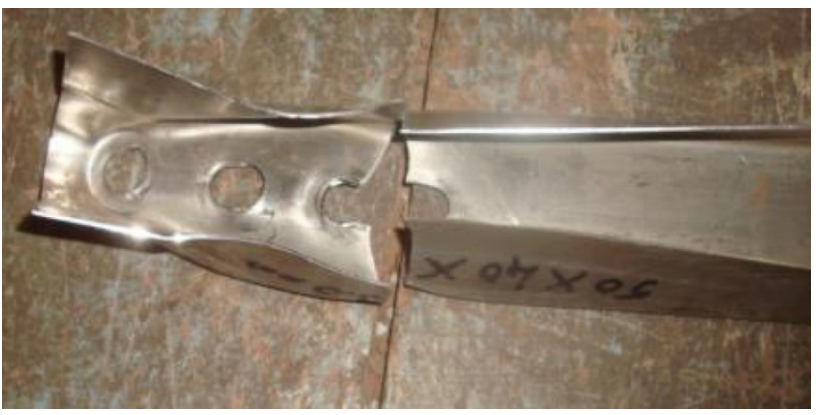

Fig. 37 Bearing + rupture failure observed

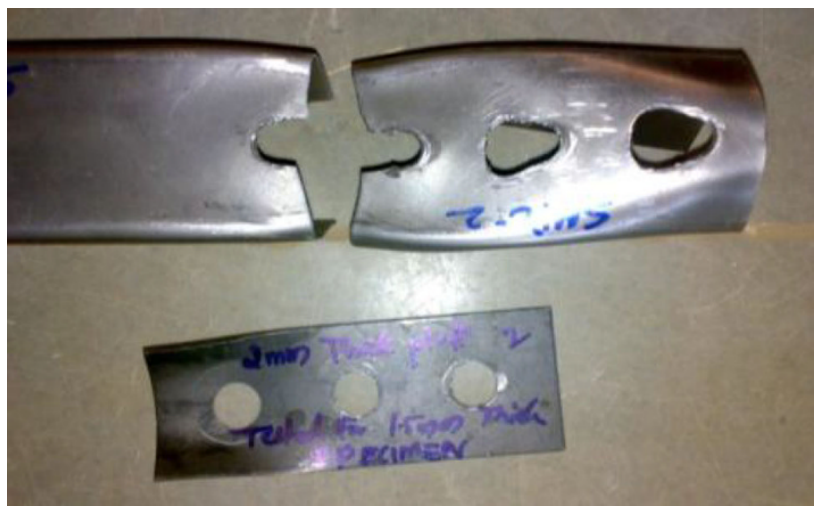

Fig. 38 Bearing + rupture failure observed with $2 \mathrm{~mm}$ thick packing plate for 1.2 and $1.5 \mathrm{~mm}$ thick specimen sample

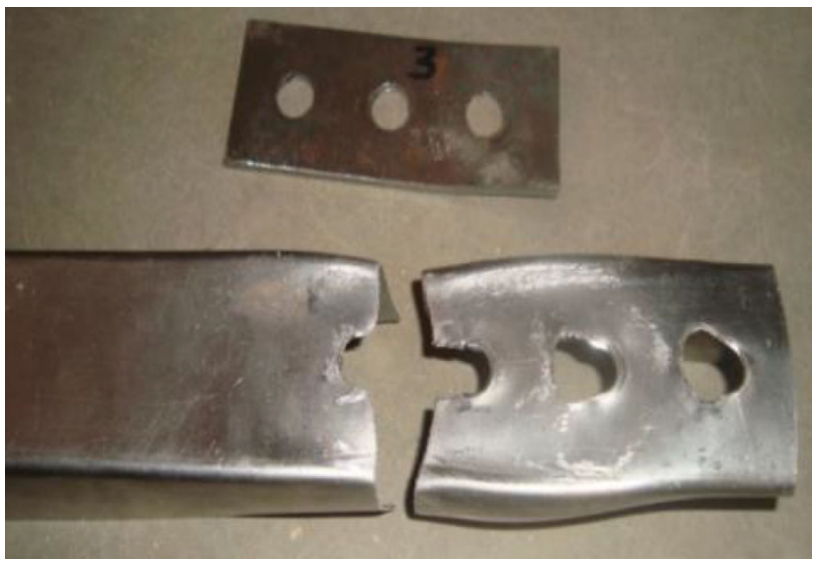

Fig. 39 Bearing + rupture failure observed with $3 \mathrm{~mm}$ thick packing plate for 1.2 , and $1.5 \mathrm{~mm}$ thick specimen sample

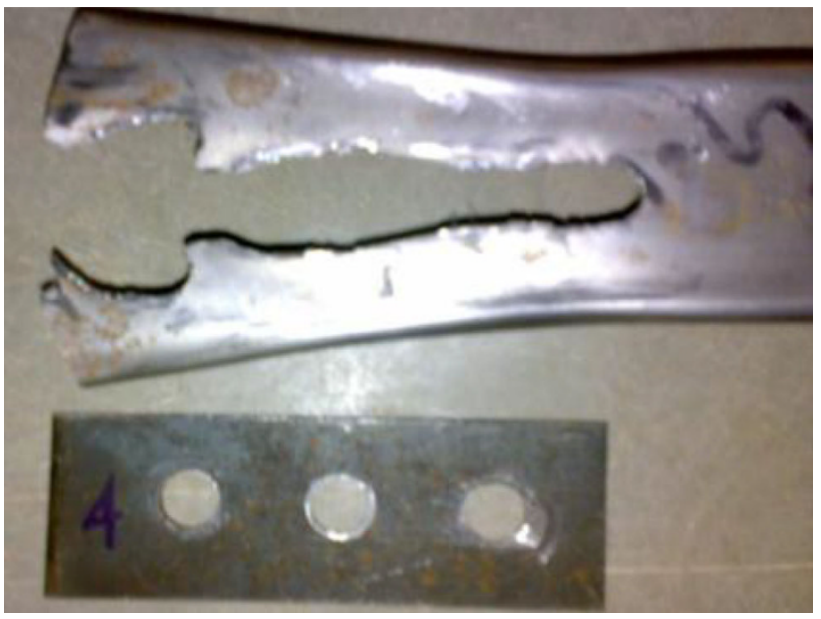

Fig. 40 Longitudinal shear failure of $1.5 \mathrm{~mm}$ thick sample specimen using $4 \mathrm{~mm}$ thick packing plate 


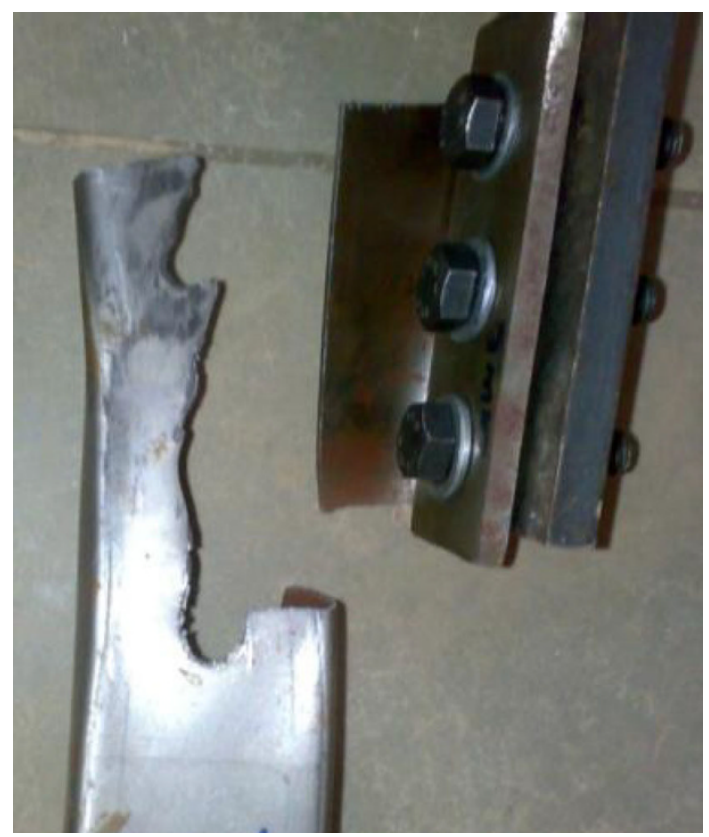

Fig. 41 Block shear failure of $1.5 \mathrm{~mm}$ thick sample specimen using $5 \mathrm{~mm}$ thick packing plate

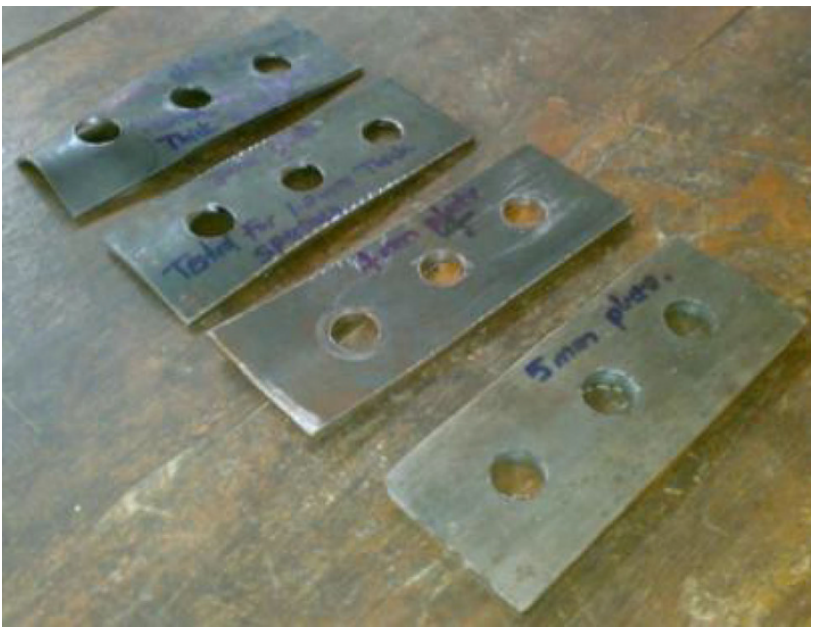

Fig. 42 Buckling of packing plate used $1.5 \mathrm{~mm}$ thick sample specimen

5. For $1.5 \mathrm{~mm}$ thick channel section with single bolt at $3 \mathrm{~d}$ end distance, it is observed that the failure is due to bearing and shear failure and the percentage of increase in tensile strength with $4 \mathrm{~mm}$ thick packing plate is $35.40 \%$.

6. For single bolt, there is increase of $35.4 \%$ in load carrying capacity for $4 \mathrm{~mm}$ thick packing plate. And for three bolted connection for same packing plate, there is increase of $19.6 \%$. See Fig. 32 .

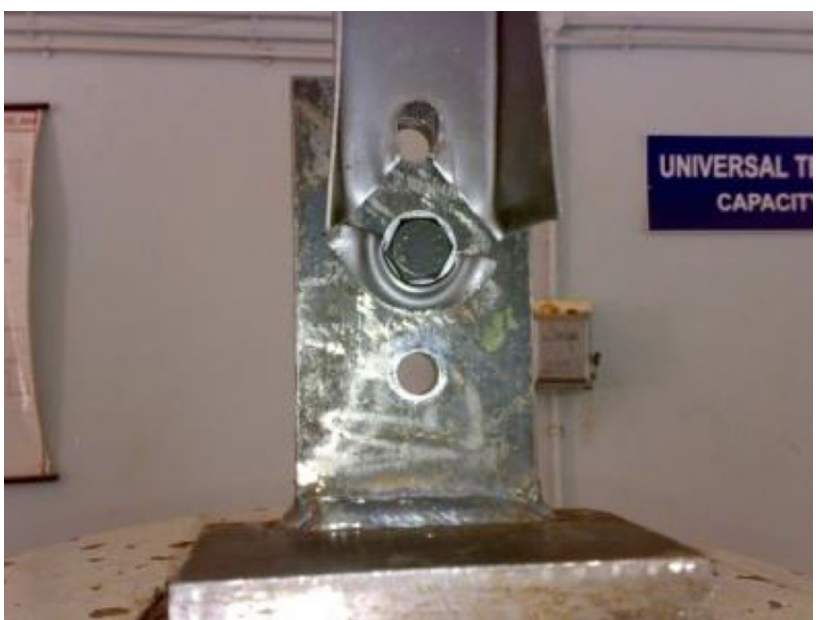

Fig. 43 Longitudinal shear failure observed for $1.5 \mathrm{~mm}$ thick specimen sample with single bolted connection

Table 8 Results of $1.2 \mathrm{~mm}$ thick channel section with three bolts at the joints

\begin{tabular}{lllll}
\hline $\begin{array}{l}\text { Size of the } \\
\text { specimen } \\
(\mathrm{mm})\end{array}$ & $\begin{array}{l}\text { Thickness } \\
\text { of packing } \\
\text { plate }(\mathrm{mm})\end{array}$ & $\begin{array}{l}\text { Ultimate } \\
\text { tensile } \\
\text { strength } \\
(\mathrm{kN})\end{array}$ & $\begin{array}{l}\text { \% of } \\
\text { increase } \\
\text { in } \\
\text { strength }\end{array}$ & $\begin{array}{l}\text { Types of } \\
\text { failure } \\
\text { observed } \\
\text { (refer Fig. 2) }\end{array}$ \\
\hline $50 \times 40 \times 1.2$ & - & 34.16 & 0 & $\mathrm{~b}, \mathrm{c}$ \\
$50 \times 40 \times 1.2$ & 2 & 35.90 & 4.6 & $\mathrm{~b}, \mathrm{c}$ \\
$50 \times 40 \times 1.2$ & 3 & 37.50 & 7.15 & $\mathrm{~b}, \mathrm{c}$ \\
$50 \times 40 \times 1.2$ & 4 & 40.90 & 19.6 & $\mathrm{~b}, \mathrm{c}$ \\
$50 \times 40 \times 1.2$ & 5 & 43.50 & 26.9 & $\mathrm{~b}, \mathrm{c}$ \\
\hline
\end{tabular}

Table 9 Results of $1.5 \mathrm{~mm}$ thick channel section with three bolts at the joints

\begin{tabular}{lllll}
\hline $\begin{array}{l}\text { Size of the } \\
\text { specimen } \\
(\mathrm{mm})\end{array}$ & $\begin{array}{l}\text { Thickness } \\
\text { of packing } \\
\text { plate }(\mathrm{mm})\end{array}$ & $\begin{array}{l}\text { Ultimate } \\
\text { tensile } \\
\text { strength } \\
(\mathrm{kN})\end{array}$ & $\begin{array}{l}\text { \% of } \\
\text { increase } \\
\text { in } \\
\text { strength }\end{array}$ & $\begin{array}{l}\text { Types of } \\
\text { failure } \\
\text { observed } \\
\text { (refer Fig. 2) }\end{array}$ \\
\hline $50 \times 40 \times 1.5$ & - & 42.40 & 0.00 & b, c \\
$50 \times 40 \times 1.5$ & 2 & 44.90 & 4.90 & b, c \\
$50 \times 40 \times 1.5$ & 3 & 46.90 & 9.50 & b, c \\
$50 \times 40 \times 1.5$ & 4 & 48.80 & 14.00 & a \\
$50 \times 40 \times 1.5$ & 5 & 50.40 & 20.00 & Block shear \\
\hline
\end{tabular}

Table 10 Results of $1.5 \mathrm{~mm}$ thick channel section with single bolt at joint

\begin{tabular}{lllll}
\hline $\begin{array}{l}\text { Size of the } \\
\text { specimen } \\
(\mathrm{mm})\end{array}$ & $\begin{array}{l}\text { Thickness } \\
\text { of packing } \\
\text { plate }(\mathrm{mm})\end{array}$ & $\begin{array}{l}\text { Ultimate } \\
\text { tensile } \\
\text { strength } \\
(\mathrm{kN})\end{array}$ & $\begin{array}{l}\text { \% of } \\
\text { increase } \\
\text { in } \\
\text { strength }\end{array}$ & $\begin{array}{l}\text { Types of } \\
\text { failure } \\
\text { observed } \\
\text { (refer Fig. 2) }\end{array}$ \\
\hline $50 \times 40 \times 1.5$ & - & 12.85 & 0.00 & a \\
$50 \times 40 \times 1.5$ & 4 & 17.40 & 35.40 & b, c \\
\hline
\end{tabular}


Open Access This article is distributed under the terms of the Creative Commons Attribution License which permits any use, distribution, and reproduction in any medium, provided the original author(s) and the source are credited.

\section{References}

Ali BA, Saad S, Osman M (2010) Coldformed steel frame with bolted moment connections

Barth et al. [9] (2002) studied "Behavior of steel tension members subjected to uniaxial loading"

Bolandim EA, Beck AT, Malite M (2013) Bolted connections in coldformed steel: reliability analysis for rupture in net section

Bouchair et al. [16] (2008) studied "Analysis of the behavior of stainless steel bolted connections"

Chen WW (2010) Cold formed steel structures. Structural engineering hand book

Hong JK, Sato A, Uang CM, Wood K (2008) Cyclic testing of coldformed steel special bolted moment frame connections

Kulak and $\mathrm{Wu}$ [7] (1997) "Shear lag in bolted angle tension members"

Kumar D (2009) Failure mode of steel in tension member due to change in connection eccentricity and connection length
Mahmood MT, Thong CM, Tan CS (2012) Performance of locally produced cold formed steel sections for roof truss system

Maiola CH, Maliti M, Gonfalvei RM, Net JM (2002) Structural behavior of bolted connections in cold-formed steel members, emphasizing the shear lag effect

Meiyalagan M, Anbarasu M, Sukumar S (2010) Investigation on cold formed $\mathrm{C}$ section long column with intermediate packing and corner lips under axial compression

Munse and Chesson [1] (1963) "Riveted and bolted joints"

Pan [11] (2004) studied "The prediction of the strength of bolted cold-formed channel sections in tension"

Pan CL (2004) Prediction of the strength of bolted cold-formed channel sections in tension

Prabha P, Saravanan M, Marimuthu V, Arul Jayachandran S (2010) Experimental studies on cold-formed steel angle tension members

Rogers CA, Hancock GJ (2000) Failure modes of bolted sheet steel

Satish Kumar SR, Santha Kumar AR (2002) Bolted connections

Wallace JA (2002) Testing of bolted cold formed steel connections in bearing (with and without washers)

Zhao XL, Wilkinson T, Hancock G (2005) Cold formed tubular members and connections 